\title{
Political Economy of Work and Employability Educational Challenges and Boundaryless Careers of Youth
}

\author{
Mei-Ling Lin \\ Department of Social Science, National Open University, Taipei, Taiwan, R.O.C \\ Email address: \\ paulina@kcg.gov.tw \\ To cite this article: \\ Mei-Ling Lin. Political Economy of Work and Employability Educational Challenges and Boundaryless Careers of Youth. Humanities and \\ Social Sciences. Vol. 5, No. 6, 2017, pp. 192-205. doi: 10.11648/j.hss.20170506.11
}

Received: September 14, 2017; Accepted: October 19, 2017; Published: November 29, 2017

\begin{abstract}
The convergence of an aging society, knowledge economy, and professional labor mobility introduces issues for education. Societies are approaching a norm of social politics organized around flexible labor markets and structural exclusion which alters the access to social inclusion through education and employment. The analysis of national education and employment policy is important in the context of a contemporary crisis of capital. The local communities, Taiwan accommodates global capital by deregulating and opening up its markets, takes active interest in the competition for the best brains, and develops a cosmopolitan outlook. The author addresses the rescaling processes affecting Taiwan in which youth are settling. The aim of this paper is to examine some key aspects of social change in Taiwan, which has undergone significant changes in its occupational structure, labor market, economy, and educational provision since the 1980s. The material of the paper draws on three levels. The first deals with the structural and institutional transformations, and some key aspects in its political economy, labor market and education. The second is concerned with occupational and social mobility patterns and trends, and their association with the changing role of education. Finally, this paper explores the experiences of youth to gain an understanding of the social, political, and cultural factors that impinge on school-to-work and social mobility outcomes.
\end{abstract}

Keywords: Boundaryless Careers, Employable Workforces, Labor Market, Young

\section{Introduction}

Globalization produces a reconfiguration of the mobility of capital. The increasing mobility across national borders obliges states to face new kinds of working relations and other changes. The growing competition has led to a drastic increase in labour market risks, and has significant consequences for the life courses and employment trajectories of individuals, above all for young people. The socio-economic context of careers has changed from traditional bureaucratic careers to ones described as boundary-less, so that workers must be protean in adjusting to different work contexts. Young people face a world of work filled with uncertainties in the context of intensifying global competition and contractual flexibility. They are entering the labour market at a time of flexible labour market regulations that have contributed to an increase in atypical and precarious employment and high job mobility and have turned into a flexible mass. The changing structure of jobs is a critical factor shaping the nature of a country's path of development and the distribution of opportunities for employment.
Human resources have become increasingly dynamic, and are expected to contribute to the competitive advantage. The growing demand for highly skilled workers and the demographic decline create economic opportunities for migrants. Migration is a feature of the international political economy, and presents the possibility of bringing in new skills or new talents. The local communities are concerned about international competition for high-skilled labor and the importance of global talent for economic competitiveness. They recognize the value of human capital for economic development, so that a growing number of them court highly skilled labor. An education function determines the individuals' human capital. Active labour market policy shifts from economic to social policy, and its objective becomes the preservation of human capital and social cohesion in the context of unemployment. Unemployment is a problem to be addressed through active labour market policies and education. Education is at the core of this analysis. The competing demands for skills that promote economic development have far-reaching implications for youth livelihoods and national 
development and merit further investigation.

Access to the labour market and to stable employment is a core characteristic for understanding social inequalities and the risk of social exclusion. The growth of middle-wage jobs is crucial to the expansion of the middle class that its decline may contribute to worsening prospects for social mobility. But the feature of economic restructuring has been the decline of middle-wage jobs, driven especially by the collapse of manufacturing employment. Understanding job polarization is key to efforts to improve the life chances of middle- and lower-wage workers. The Taiwan economy is globalizing rapidly as transnational capital investment flows have sought new localities to establish productive infrastructure, and moves from mass-production to professional-services that is knowledge-intensive. Competitive advantage of Taiwan is increasingly derived from human resources. These circumstances raise important questions regarding how we go about understanding the relationship between economic growth and labour flows. The paper charts how these issues influence policy development and examines some of the critiques of the work-education nexus in a global context.

\section{Method}

\subsection{Aims \& Underlying Assumptions}

The local communities, Taiwan has seen an increase in the intensity and scope of cross-border interactive relationships. We aim to disentangle the strategy applied by Taiwan to adapt its national labour markets to increasing globalization and flexibility demands, and to investigate what these differential strategies imply for the development of social inequalities. The concern is to examine the changes in the variables, GDP, productivity and employment, in Taiwan over the periods of downturn since 1980s. The author uses datasets derived from studies with young workers to explore the experiences of workers transitioning into and out of the labour market. The aim is to investigate what types of career transitions, the reasons behind those transitions, and the support provided to those making transitions. It has been interesting for us to verify at what level the idea of flexibility develops in young people, by analyzing the work and career expectations of young people and the development of the protean career.

The paper focuses on the inequality effects of the process of labour market flexibilization, depicting various forms of social, economic, and demographic consequences that impact on young people in Taiwan. We will discuss how the social divisions due to the flexibilization of work are reflected in the career trajectories of young people. This paper is divided into 4 parts. First, we summarize some background characteristics of the Taiwan employment regime. It starts from a theoretical perspective by sketching the characteristics of the globalization process and its effects on labour market processes. Second, we discuss changes in the labour market and educational system since 1980s. Third, we discuss how these changes have impacted on Taiwan workers' career trajectories and how these have influenced patterns of social inequality. The educational systems bear significant influences on human-capital formation. We use empirical quantitative and qualitative data to discuss the experiences of young workers entering the labour market. A final summary reflects on the key finding of this paper, its contribution to the research arena, as well as open questions for future research.

\subsection{The Data Sources and Measures}

A fundamental source of data comes from government documents and reports, official statistics, the Directorate General of Budget, Accounting and Statistics (DGBAS) of Executive Yuan, and Workforce Development Agency, Ministry of Labor (MOL) of Executive Yuan, and budget documents. There is a need for theoretical discussions on how to understand the concepts of the political economy of work and employability. The statistic data cover the following main themes: labor force participation rate (including sex, age and education), financial issues (including current income source, economic growth, GDP, GNI, NI, disposable income), and foreign workers (including number, nationality, categories of work). These data are combined with data on labour inputs and productivity from the statistics database in relation to the recent period, 1980-2016. More detailed data on employment from the Taiwan Labour Force Survey are used to describe employment shifts at occupational level during the great recession. The concern is to examine the changes in the variables GDP, productivity, average month worked and employment. The quantitative analysis can be complemented with some qualitative information about what specific jobs are common among the young people and how this picture compares with locals. To fulfill our aims, we will introduce the international literature on the educational challenges, boundaryless careers and youth and then describe our explorative study, adding concluding remarks on a future research agenda related to this topic.

\subsection{Theoretical Foundations}

Globalization is flourishing cross-world mobility [1]. The vehicle of international labor mobility is skilled immigration which provides a foreign-born professional the opportunity to work freely [2]. Knowledge and other human-based intangibles have become the resources for wealth creation [3]. The more knowledgeable the worker is, the more likely he (she) is to be employable [4]. Economies are becoming knowledge based, which require a skilled workforce to maintain economic viability [5]. Highly skilled migrants tend to the professional development and employment opportunities [6]. The increase in the number of international migrants translates into more migrants seeking to cross borders [7]. States face economic pressures stemming from demographic changes, skill retention, and their capacity to compete innovatively [8]. They accommodate global capital by deregulating and opening up their markets [9]. Young people tend to engage more in circular mobility which is defined as international or temporary migration for economic reasons [10]. A rethinking of immigration policy reflects the 
state's role in facilitating a broader socio-economic transformation [11].

Labour market deregulation has played a major role in growing heterogeneity in the labour market [12]. Nonstandard work is designed to attract highly productive and highly skilled workers, helps bring investment and increases productivity and flexibility in the labour market [13]. For today's new entrant to the labour market, securing fulltime and permanent work has become the exception rather than the rule [14]. Flexible working arrangements include not only nonstandard work schedules such as part-time work or flexi-time, but also measures as diverse as shift work, and temporary employment [15]. Younger cohorts will work atypically [16]. The processes of globalization lead to a re-commodification of already disadvantaged groups of the workforce and to a strengthening of already existing social inequalities [17]. Unskilled and semi-skilled workers are affected by employment flexibilization [18]. Countries with a higher level of human development perform better in terms of GDP growth, therefore, a higher level of human development seems to be the major cause of faster economic growth [19]. Equality of opportunity is seen through investment in education which would provide individuals with the means to lay the foundations for a skilled and mobile workforce [20]. Education as a social public good is necessary for creating workers to fuel a healthy economy [21]. Younger generations that have benefited from the process of educational expansion are able to escape from the atypical work trap by transforming their flexible contracts into permanent ones [22].

\section{Result: Local Community in Its Global Context}

The shift towards recognition of an education-work nexus has occurred within the broader context of a globalized knowledge economy and a global race for skills. The local communities, Taiwan is in constant competition for its share of the international market and for the best skilled talent pool. The Taiwan economy confronts a wide range of contradictory pressures to cope with increased levels of uncertainty, while also responding to its population demands for security and social cohesion. Industrial relations, employment laws and policies and social policies are confronted with new challenges. The paper moves further into the investigation of how well the diverse segments of the population are making the transition from the local economies into the global economy.

\subsection{Boundaryless Career}

Taiwan determines to reverse the drain of top talent that accompanies its opening to the outside world. Taiwan begins tapping into the highly educated diaspora overseas, and launchs an aggressive campaign to induce more overseas students to return. US educated engineers of Taiwanese origin contribute to the development of the home country's information technology industry. Active involvement and support build industrial parks, strengthen the science and technology infrastructure, and provide incentives to draw researchers back to Taiwan. Temporary foreign workers have played a critical role supplying labour, and foreign workers are considered to be a structural necessity for the industry. Governments have been pursuing a variety of policies to maximize the development impacts of international migration. International graduates of local universities are also seen as fitting the model of the desirable worker.

By national income in Taiwan, the rate of economic growth has decreased from 8.36 in 1991 to -1.26 in 2001, from 0.70 in 2008 to -1.57 in 2009 , and then 1.40 in 2016; the amount (US\$) of Gross Domestic Product (Per Capita GDP) develops from 9,136 in 1991 to 13,448 in 2001 , from 18,131 in 2008 to 16,988 in 2009 , and then 22,495 in 2016 , which is shown in Table 1. Over the course of the period 1991 to 2016, GDP, GNI and NI for Taiwan grow nearly 3 times overall. The approach calls on Taiwan not only to restructure its economic systems and reorder its fiscal and monetary priorities, but also to improve performance through improved bureaucratic accountability. There is some sign as a whole of the share of managers and professionals (engineers, professional, scientific \& technical services and so on) increasing as total employment declined from 2000 onwards. According to "Foreign Workers for Special Professions or Technical Assignments by Educational Attainment and Industry in Taiwan", the top 6 priorities of the number of "persons of effective employment permit" are follows: "Education", "Manufacturing", "Wholesale \& retail trade", "Professional, scientific \& technical services", "Arts \& entertainment \& recreation", "Information \& communication"; the last 2 priorities of the number are follows: "Mining \& quarrying", "Agriculture \& forestry \& fishing \& animal husbandry", which is shown in Table 2. The share of skilled and semi-skilled manual workers in employment declined closely in line with each other as the share of managers and professionals rose.

Table 1. Principal Figures in Taiwan, End of 1991-2016.

\begin{tabular}{|c|c|c|c|c|c|c|c|c|c|}
\hline \multirow{3}{*}{ Year } & \multirow{2}{*}{$\begin{array}{l}\text { Average } \\
\text { Population }\end{array}$} & \multirow{2}{*}{$\begin{array}{l}\text { Exchange Rates of } \\
\text { the NTS against the } \\
\text { US\$ }\end{array}$} & \multirow{2}{*}{$\begin{array}{l}\text { Economic } \\
\text { Growth } \\
\text { Rate } \\
\end{array}$} & \multicolumn{2}{|c|}{ Nominal GDP } & \multicolumn{2}{|c|}{ Nominal GNI } & \multicolumn{2}{|l|}{ Nominal NI } \\
\hline & & & & $\begin{array}{l}\text { Nominal } \\
\text { GDP }\end{array}$ & $\begin{array}{l}\text { Per Capita } \\
\text { GDP }\end{array}$ & $\begin{array}{l}\text { Nominal } \\
\text { GNI }\end{array}$ & $\begin{array}{l}\text { Per Capita } \\
\text { GNI }\end{array}$ & Nominal NI & $\begin{array}{l}\text { Per Capita } \\
\text { NI }\end{array}$ \\
\hline & persons & $\begin{array}{l}\text { Average of daily } \\
\text { figures }\end{array}$ & $\%$ & $\begin{array}{l}\text { million } \\
\text { US\$ }\end{array}$ & US\$ & $\begin{array}{l}\text { million } \\
\text { US\$ }\end{array}$ & US\$ & million US\$ & US\$ \\
\hline 1991 & $20,503,568$ & 26.82 & 8.36 & 187,314 & 9,136 & 192,368 & 9,382 & 174,722 & 8,522 \\
\hline 1992 & $20,704,227$ & 25.16 & 8.29 & 223,159 & 10,778 & 227,959 & 11,010 & 204,606 & 9,882 \\
\hline 1993 & $20,899,019$ & 26.39 & 6.80 & 235,140 & 11,251 & 239,461 & 11,458 & 215,297 & 10,302 \\
\hline 1995 & $21,267,653$ & 26.49 & 6.50 & 279,224 & 13,129 & 283,411 & 13,326 & 253,664 & 11,927 \\
\hline
\end{tabular}




\begin{tabular}{|c|c|c|c|c|c|c|c|c|c|}
\hline \multirow{3}{*}{ Year } & \multirow[b]{2}{*}{$\begin{array}{l}\text { Average } \\
\text { Population }\end{array}$} & \multirow{2}{*}{$\begin{array}{l}\text { Exchange Rates of } \\
\text { the NT\$ against the } \\
\text { US\$ }\end{array}$} & \multirow{2}{*}{$\begin{array}{l}\text { Economic } \\
\text { Growth } \\
\text { Rate } \\
\end{array}$} & \multicolumn{2}{|c|}{ Nominal GDP } & \multicolumn{2}{|c|}{ Nominal GNI } & \multicolumn{2}{|l|}{ Nominal NI } \\
\hline & & & & $\begin{array}{l}\text { Nominal } \\
\text { GDP }\end{array}$ & $\begin{array}{l}\text { Per Capita } \\
\text { GDP }\end{array}$ & $\begin{array}{l}\text { Nominal } \\
\text { GNI }\end{array}$ & $\begin{array}{l}\text { Per Capita } \\
\text { GNI }\end{array}$ & Nominal NI & $\begin{array}{l}\text { Per Capita } \\
\text { NI }\end{array}$ \\
\hline & persons & $\begin{array}{l}\text { Average of daily } \\
\text { figures }\end{array}$ & $\%$ & $\begin{array}{l}\text { million } \\
\text { US\$ }\end{array}$ & US\$ & $\begin{array}{l}\text { million } \\
\text { US\$ }\end{array}$ & US\$ & million US\$ & US\$ \\
\hline 1996 & $21,441,432$ & 27.46 & 6.18 & 292,665 & 13,650 & 296,653 & 13,836 & 265,856 & 12,399 \\
\hline 1997 & $21,634,124$ & 28.70 & 6.11 & 303,737 & 14,040 & 306,859 & 14,184 & 275,525 & 12,736 \\
\hline 1998 & $21,835,703$ & 33.46 & 4.21 & 280,369 & 12,840 & 282,418 & 12,934 & 250,950 & 11,493 \\
\hline 1999 & $22,010,489$ & 32.27 & 6.72 & 304,171 & 13,819 & 306,976 & 13,947 & 271,772 & 12,347 \\
\hline 2000 & $22,184,530$ & 31.23 & 6.42 & 331,452 & 14,941 & 335,921 & 15,142 & 296,816 & 13,379 \\
\hline 2001 & $22,341,120$ & 33.81 & -1.26 & 300,450 & 13,448 & 306,129 & 13,703 & 266,664 & 11,936 \\
\hline 2002 & $22,463,172$ & 34.58 & 5.57 & 308,875 & 13,750 & 315,887 & 14,062 & 274,853 & 12,236 \\
\hline 2003 & $22,562,663$ & 34.42 & 4.12 & 318,590 & 14,120 & 328,145 & 14,544 & 287,190 & 12,729 \\
\hline 2004 & $22,646,836$ & 33.43 & 6.51 & 348,479 & 15,388 & 359,609 & 15,879 & 313,121 & 13,826 \\
\hline 2005 & $22,729,753$ & 32.18 & 5.42 & 375,769 & 16,532 & 384,808 & 16,930 & 333,521 & 14,673 \\
\hline 2006 & $22,823,455$ & 32.53 & 5.62 & 388,589 & 17,026 & 398,171 & 17,446 & 341,757 & 14,974 \\
\hline 2007 & $22,917,444$ & 32.84 & 6.52 & 408,254 & 17,814 & 418,387 & 18,256 & 352,952 & 15,401 \\
\hline 2008 & $22,997,696$ & 31.54 & 0.70 & 416,961 & 18,131 & 426,937 & 18,564 & 353,896 & 15,388 \\
\hline 2009 & $23,078,402$ & 33.06 & -1.57 & 392,065 & 16,988 & 404,587 & 17,531 & 332,285 & 14,398 \\
\hline 2010 & $23,140,948$ & 31.65 & 10.63 & 446,105 & 19,278 & 459,679 & 19,864 & 385,290 & 16,650 \\
\hline 2011 & $23,193,518$ & 29.47 & 3.80 & 485,653 & 20,939 & 498,832 & 21,507 & 417,057 & 17,982 \\
\hline 2012 & $23,270,367$ & 29.62 & 2.06 & 495,845 & 21,308 & 511,179 & 21,967 & 421,779 & 18,125 \\
\hline 2013 & $23,344,670$ & 29.77 & 2.20 & 511,614 & 21,916 & 525,851 & 22,526 & 440,559 & 18,872 \\
\hline 2014 & $23,403,635$ & 30.37 & 4.02 & 530,519 & 22,668 & 546,013 & 23,330 & 461,605 & 19,724 \\
\hline 2015 & $23,462,914$ & 31.91 & 0.72 & 525,196 & 22,384 & 542,711 & 23,131 & 458,475 & 19,540 \\
\hline 2016 & $23,515,945$ & 32.33 & 1.40 & 528,866 & 22,495 & 547,224 & 23,277 & 461,400 & 19,626 \\
\hline
\end{tabular}

Source: Directorate General of Budget, Accounting and Statistics (DGBAS) of Executive Yuan, R.O.C.

Table 2. Foreign Workers for Special Professions or Technical Assignments by Educational Attainment and Industry in Taiwan, End of Dec., 2016.

\begin{tabular}{|c|c|c|c|}
\hline Item & $\begin{array}{l}\text { Accumulation of } \\
\text { application }\end{array}$ & $\begin{array}{l}\text { Accumulation of } \\
\text { the employment permit }\end{array}$ & $\begin{array}{l}\text { Persons of effective } \\
\text { employment permit }\end{array}$ \\
\hline Grand total & 467,464 & 450,183 & 31,025 \\
\hline By Educational Attainment & - & - & - \\
\hline Under Senior school & 118,561 & 113,351 & 5,334 \\
\hline Junior college & 291,994 & 281,518 & 19,191 \\
\hline Master & 40,058 & 38,830 & 5,006 \\
\hline Doctor & 16,176 & 15,831 & 1,494 \\
\hline Others & 675 & 653 & - \\
\hline By industry & - & - & - \\
\hline Agriculture, forestry, fishing \& animal husbandry & 81 & 70 & 14 \\
\hline Mining \& quarrying & 39 & 38 & 2 \\
\hline Manufacturing & 57,205 & 55,537 & 6,338 \\
\hline Electricity \& gas supply & 1,268 & 1,261 & 9 \\
\hline Water supply \& remediation services & 250 & 230 & 21 \\
\hline Construction & 14,307 & 14,003 & 980 \\
\hline Wholesale \& retail trade & 45,485 & 43,034 & 5,775 \\
\hline Transportation \& storage & 6,999 & 6,880 & 916 \\
\hline Accommodation \& food services & 5,960 & 5,319 & 839 \\
\hline Information \& communication & 16,163 & 15,179 & 1,326 \\
\hline Financial \& insurance & 4,295 & 4,209 & 466 \\
\hline Real estate & 439 & 403 & 65 \\
\hline Professional, scientific \& technical services & 69,680 & 66,894 & 3,712 \\
\hline Support services & 7,296 & 7,141 & 180 \\
\hline Public administration \& defence; Compulsory social security & 7,325 & 7,158 & 24 \\
\hline Education & - & - & - \\
\hline Human health \& social work services & 122,868 & 119,554 & 7,830 \\
\hline Arts, entertainment \& recreation & 5,628 & 5,398 & 655 \\
\hline Other services & 81,026 & 77,583 & 1,464 \\
\hline \multirow[t]{2}{*}{ Others } & 20,562 & 19,735 & 409 \\
\hline & 588 & 557 & - \\
\hline
\end{tabular}

Source: Workforce Development Agency, Ministry of Labor (MOL) of Executive Yuan

Unit: Person-case

\subsection{Youth}

Young people have been confronted with increasing labour market insecurity and a delayed integration into employment. Young labour market entrants are equipped with fixed-term contracts and find it increasingly difficult to establish 
themselves securely in employment. Today's young workers are of no longer expecting a job-for-life from their employers, and are said to face more difficult routes to employment in comparison with previous generations. It is important to remember that Taiwan has a low level of force participation rate of youth: the rate of "15 19 years" group has decreased from 44.72 in 1978 to 8.60 in 2016, and the rate of "20 24 years" group also has decreased from 65.16 in 1978 to 53.53 in 2016, which is shown in Table 3. Moreover, Taiwan has a high level of unemployment rate of youth. The rate of "15 19 years" group has grown from 3.95 in 1978 to 8.94 in 2016, and the rate of "20 24 years" group also has grown from 3.77 in 1978 to 12.62 in 2016, which is shown in Table 4. The Taiwan youth labor force participation rate currently lags behind. Taiwan faces a growing youth population that is unable to secure sustainable employment. More young people combine flexible employment with further investments in educational degrees. While more young people are attending higher education, they are learning the knowledge and skills needed for the changing market economy.

Table 3. Labor Force Participation Rate by Age in Taiwan, End of 1978-2016.

\begin{tabular}{|c|c|c|c|c|c|c|c|c|c|c|c|}
\hline Year & $\begin{array}{l}15 \sim 19 \\
\text { years }\end{array}$ & $\begin{array}{l}20 \sim 24 \\
\text { years }\end{array}$ & $\begin{array}{l}25 \sim 29 \\
\text { years }\end{array}$ & $\begin{array}{l}30 \sim 34 \\
\text { years }\end{array}$ & $\begin{array}{l}35 \sim 39 \\
\text { years }\end{array}$ & $\begin{array}{l}40 \sim 44 \\
\text { years }\end{array}$ & $\begin{array}{l}45 \sim 49 \\
\text { years }\end{array}$ & $\begin{array}{l}50 \sim 54 \\
\text { years }\end{array}$ & $\begin{array}{l}55 \sim 59 \\
\text { years } \\
\end{array}$ & $\begin{array}{l}60 \sim 64 \\
\text { years }\end{array}$ & $\begin{array}{l}65 \text { years } \\
\& \text { over }\end{array}$ \\
\hline 1978 & 44.72 & 65.16 & 68.39 & 69.48 & 70.60 & 70.53 & 69.21 & 65.36 & 56.81 & 43.53 & 9.48 \\
\hline 1980 & 41.57 & 65.30 & 68.96 & 68.75 & 72.13 & 70.86 & 69.62 & 66.02 & 56.30 & 40.83 & 8.48 \\
\hline 1990 & 24.68 & 65.73 & 76.32 & 75.67 & 76.60 & 76.21 & 72.33 & 65.04 & 56.43 & 40.90 & 9.77 \\
\hline 2000 & 15.14 & 59.41 & 81.22 & 80.08 & 79.15 & 78.04 & 73.43 & 63.91 & 50.54 & 35.68 & 7.71 \\
\hline 2008 & 9.74 & 51.66 & 85.02 & 84.75 & 83.86 & 81.56 & 76.18 & 65.94 & 50.60 & 31.86 & 8.10 \\
\hline 2009 & 8.84 & 49.64 & 85.82 & 85.18 & 84.24 & 81.45 & 76.62 & 65.43 & 49.95 & 31.75 & 8.05 \\
\hline 2012 & 8.45 & 51.65 & 91.87 & 86.40 & 83.96 & 83.60 & 78.70 & 67.73 & 52.52 & 32.56 & 8.10 \\
\hline 2013 & 8.11 & 52.73 & 92.50 & 86.71 & 84.10 & 84.02 & 79.56 & 68.27 & 53.21 & 33.42 & 8.34 \\
\hline 2014 & 7.98 & 51.35 & 91.67 & 88.19 & 83.77 & 84.48 & 80.21 & 69.63 & 54.41 & 35.61 & 8.68 \\
\hline 2015 & 8.35 & 52.15 & 92.49 & 89.38 & 83.87 & 84.86 & 80.92 & 70.34 & 55.08 & 35.77 & 8.78 \\
\hline 2016 & 8.60 & 53.53 & 92.23 & 90.16 & 84.71 & 85.16 & 81.68 & 71.44 & 55.67 & 36.35 & 8.61 \\
\hline
\end{tabular}

Source: Directorate General of Budget, Accounting and Statistics (DGBAS) of Executive Yuan, R.O.C.

Unit: \%

Table 4. Unemployment Rate by age in Taiwan, End of 1978-2016.

\begin{tabular}{|c|c|c|c|c|c|c|c|c|c|c|c|}
\hline Year & $\begin{array}{l}15 \sim 19 \\
\text { years }\end{array}$ & $\begin{array}{l}20 \sim 24 \\
\text { years }\end{array}$ & $\begin{array}{l}25 \sim 29 \\
\text { years }\end{array}$ & $\begin{array}{l}30 \sim 34 \\
\text { years }\end{array}$ & $\begin{array}{l}35 \sim 39 \\
\text { years }\end{array}$ & $\begin{array}{l}40 \sim 44 \\
\text { years }\end{array}$ & $\begin{array}{l}45 \sim 49 \\
\text { years }\end{array}$ & $\begin{array}{l}50 \sim 54 \\
\text { years }\end{array}$ & $\begin{array}{l}55 \sim 59 \\
\text { years }\end{array}$ & $\begin{array}{l}60 \sim 64 \\
\text { years }\end{array}$ & $\begin{array}{l}65 \text { years } \\
\text { \& over }\end{array}$ \\
\hline 1978 & 3.95 & 3.77 & 1.54 & 0.64 & 0.38 & 0.43 & 0.43 & 0.82 & 0.76 & 0.43 & 0.17 \\
\hline 1980 & 3.21 & 3.13 & 1.09 & 0.44 & 0.31 & 0.19 & 0.29 & 0.43 & 0.44 & 0.29 & - \\
\hline 1990 & 5.68 & 4.79 & 1.92 & 0.99 & 0.84 & 0.64 & 0.64 & 0.52 & 0.36 & 0.22 & 0.03 \\
\hline 2000 & 9.04 & 6.89 & 3.77 & 2.59 & 2.24 & 1.98 & 1.93 & 1.85 & 1.61 & 0.92 & 0.24 \\
\hline 2008 & 11.42 & 11.89 & 6.38 & 3.89 & 2.97 & 2.63 & 2.76 & 2.65 & 2.33 & 1.38 & 0.17 \\
\hline 2009 & 13.55 & 14.67 & 8.77 & 5.82 & 4.64 & 4.23 & 4.27 & 4.14 & 3.54 & 2.00 & 0.13 \\
\hline 2011 & 11.22 & 12.71 & 7.11 & 4.32 & 3.32 & 3.02 & 2.99 & 2.66 & 2.44 & 1.57 & 0.15 \\
\hline 2012 & 9.80 & 13.17 & 7.08 & 4.34 & 3.37 & 2.76 & 2.55 & 2.35 & 2.14 & 1.69 & 0.17 \\
\hline 2013 & 9.65 & 13.75 & 7.11 & 4.20 & 3.37 & 2.51 & 2.59 & 2.26 & 2.15 & 1.32 & 0.14 \\
\hline 2014 & 8.78 & 13.25 & 6.84 & 4.04 & 3.26 & 2.58 & 2.37 & 2.12 & 2.04 & 1.23 & 0.10 \\
\hline 2015 & 8.63 & 12.59 & 6.55 & 3.97 & 3.14 & 2.37 & 2.36 & 2.06 & 1.76 & 1.16 & 0.14 \\
\hline 2016 & 8.94 & 12.62 & 6.76 & 3.79 & 3.41 & 2.66 & 2.51 & 2.15 & 1.92 & 1.63 & 0.17 \\
\hline
\end{tabular}

Source: Directorate General of Budget, Accounting and Statistics (DGBAS) of Executive Yuan, R.O.C.

Unit: \%

\subsection{Labor Mobility}

The analysis of immigrants' performance in the Taiwan labour markets must be preceded by a brief review of the main socio-economic characteristics of this population group. Immigrants are to a large extent young people that half of immigrants are aged between 15 and 39. Large numbers of poor and low-educated immigrants from South-East Asia and China arrive and take the low-level service and labour jobs at the bottom of the wage structure. Taiwan also has robust immigrant among highly educated middle-class populations that find jobs at the top of the wage structure. The bipolar occupational distribution of migrant workers concentrates in professional occupations at the upper end of the skills distribution and elementary occupations at the lower end. In developing their businesses globally, companies are seeking to increase the diversity of their talent pool. To promote the international mindset, companies increase the nationality mix of the internationally mobile population in their internal labour markets. Highly skilled migrants are preferred. The government is taking active interest in managing its immigration to maximize its share of highly skilled workers, including for instance: expanding programs to recruit foreign workers on a temporary basis, and incentivizing spatially mobile industries to relocate to take advantage of less regulated regions.

Table 5 shows the distribution of foreign workers in productive industries and social welfare by industry in Taiwan. Several interesting facts should be highlighted. First, the 
general rule is that the total grand number of foreign workers develops from 304,605 in 2001 to 624,768 in 2016 . Over the course of the period 2001 to 2016, the number of foreign workers migrants in Taiwan grows 2 times overall, including the number of foreign workers in productive industries develops from 191,671 in 2001 to 387,477 in 2016, and the number of foreign workers in social welfare develops from 112,934 in 2001 to 237,291 in 2016 . Second, the number of foreign workers in manufacturing develops from 157,055 in
2001 to 370,222 in 2016 , but, the number of foreign workers in major investing decreases from 61,258 in 2001 to 670 in 2016. Particularly, the number of foreign workers in construction decreases from 33,367 in 2001 to 6,383 in 2016, then, the number of foreign workers in major construction projects also decreases from 29,619 in 2001 to 6,185 in 2016. It suggests that foreign workers seem to face such a severe disadvantage compared to natives, and are under-represented in the top quintiles of jobs.

Table 5. Foreign Workers in Productive Industries and Social Welfare by Industry in Taiwan, End of 2001-2016 (Cont. 1).

\begin{tabular}{|c|c|c|c|c|c|c|c|c|c|}
\hline \multirow{3}{*}{$\begin{array}{l}\text { End of } \\
\text { year }\end{array}$} & \multirow{3}{*}{$\begin{array}{l}\text { total } \\
\text { Grand }\end{array}$} & \multicolumn{8}{|c|}{ Foreign workers in productive industries } \\
\hline & & \multicolumn{3}{|c|}{ Sex } & \multirow[b]{2}{*}{$\begin{array}{l}\text { Agriculture, forestry, } \\
\text { fishing \& animal } \\
\text { husbandry (Crewmen) }\end{array}$} & \multicolumn{2}{|l|}{ Manufacturing } & \multicolumn{2}{|l|}{ Construction } \\
\hline & & Subtotal & Male & Female & & Manufacturing & $\begin{array}{l}\text { Major } \\
\text { investing }\end{array}$ & Construction & $\begin{array}{l}\text { Major } \\
\text { construction } \\
\text { projects }\end{array}$ \\
\hline 2001 & 304,605 & 191,671 & 142,498 & 49,173 & 1,249 & 157,055 & 61,258 & 33,367 & 29,619 \\
\hline 2002 & 303,684 & 182,973 & 132,125 & 50,848 & 2,935 & 156,697 & 64,183 & 23,341 & 21,191 \\
\hline 2003 & 300,150 & 179,552 & 126,592 & 52,960 & 3,396 & 162,039 & 70,354 & 14,117 & 12,747 \\
\hline 2005 & 327,396 & 183,381 & 126,184 & 57,197 & 3,147 & 166,928 & 79,569 & 13,306 & 6,193 \\
\hline 2006 & 338,755 & 184,970 & 127,827 & 57,143 & 3,322 & 169,903 & 83,993 & 11,745 & 5,884 \\
\hline 2007 & 357,937 & 195,709 & 136,990 & 58,719 & 3,786 & 183,329 & 86,582 & 8,594 & 5,992 \\
\hline 2008 & 365,060 & 196,633 & 140,141 & 56,492 & 4,865 & 185,624 & 74,757 & 6,144 & 4,467 \\
\hline 2009 & 351,016 & 176,073 & 126,762 & 49,311 & 6,452 & 165,790 & 56,573 & 3,831 & 2,725 \\
\hline 2010 & 379,653 & 193,545 & 138,281 & 55,264 & 7,745 & 182,192 & 46,644 & 3,608 & 2,833 \\
\hline 2011 & 425,660 & 227,806 & 163,809 & 63,997 & 8,670 & 215,271 & 29,348 & 3,865 & 3,313 \\
\hline 2013 & 489,134 & 278,919 & 199,252 & 79,667 & 9,788 & 265,741 & 6,190 & 3,390 & 2,848 \\
\hline 2014 & 551,596 & 331,585 & 232,530 & 99,055 & 10,316 & 316,409 & 2,609 & 4,860 & 4,318 \\
\hline 2015 & 587,940 & 363,584 & 255,667 & 107,917 & 9,898 & 346,914 & 1,200 & 6,772 & 6,413 \\
\hline 2016 & 624,768 & 387,477 & 272,585 & 114,892 & 10,872 & 370,222 & 670 & 6,383 & 6,185 \\
\hline
\end{tabular}

Source: Workforce Development Agency, Ministry of Labor (MOL) of Executive Yuan

Unit: Person

Table 5. Foreign Workers in Productive Industries and Social Welfare by Industry in Taiwan, End of 2001-2016 (Cont. 2).

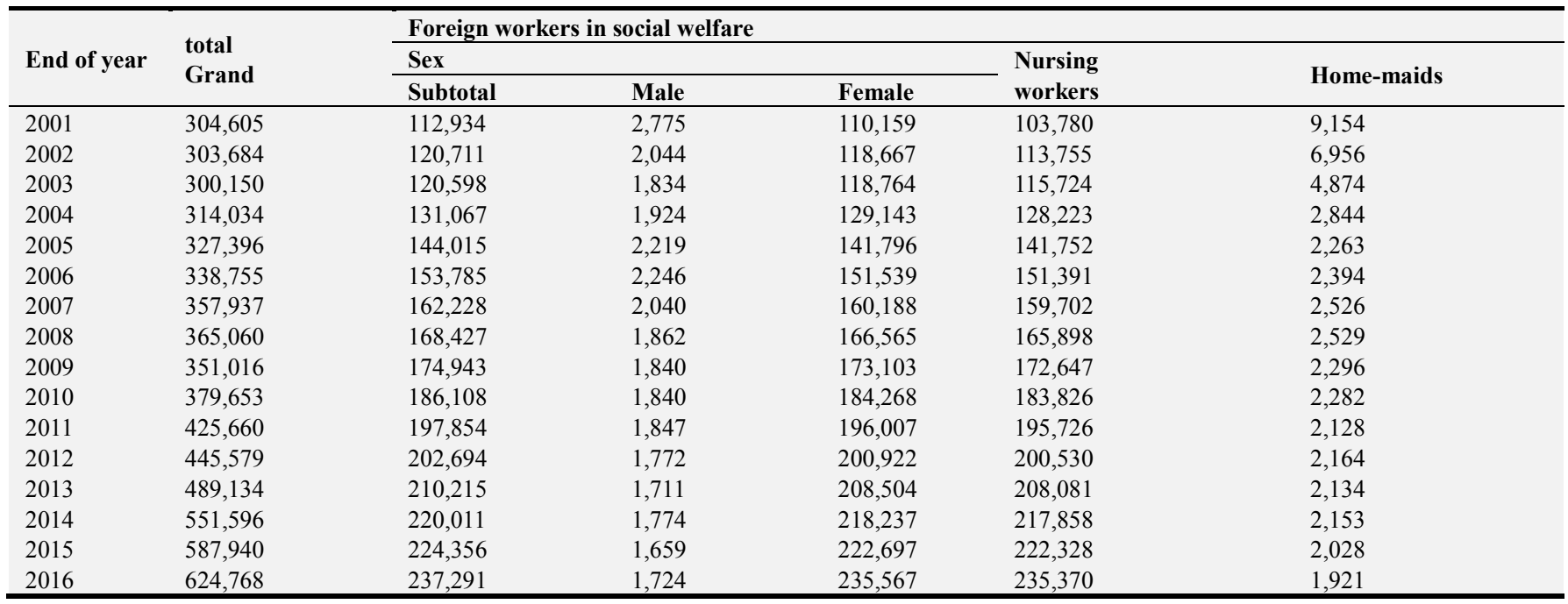

Source: Workforce Development Agency, Ministry of Labor (MOL) of Executive Yuan

Unit: Person

Table 6 shows the distribution of foreign workers for special professions or technical assignments in Taiwan. By persons of effective employment permit, the top 4 priorities of the number are follows: Specialized or technical work, Full-time teacher teaching courses on foreign languages at a short-term class registered for supplementary schooling, Director of a business invested in or set up by overseas Chinese or foreigner(s), School Teacher. Table 7 shows the distribution of foreign workers for special professions or technical assignments in Taiwan. By nationality, the top 10 
priorities of the number are follows: Japan, United States, United Kingdom, Hong Kong, Indonesia. Malaysia, Philippines, India, R.O., Korea, R.O., Canada,

Table 6. Foreign Workers for Special Professions or Technical Assignments by Sex, Categories of work in Taiwan, End of 2004-2016.

\begin{tabular}{lllllll}
\hline & \multicolumn{3}{l}{ Persons of effective employment permit } \\
\cline { 2 - 6 } End of year & $\begin{array}{l}\text { Accumulation of the } \\
\text { employment permit }\end{array}$ & Sex & & & \multicolumn{2}{c}{ Categories of Work } \\
\cline { 2 - 6 } & & Total & Male & Female & $\begin{array}{l}\text { Specialized or } \\
\text { technical work }\end{array}$ & $\begin{array}{l}\text { Religious, artistic, } \\
\text { and show business work }\end{array}$ \\
\hline 2004 & 30,266 & 20,751 & 16,474 & 4,277 & 11,228 & 1,311 \\
2005 & 63,755 & 25,933 & 20,930 & 5,003 & 13,118 & 1,516 \\
2006 & 99,588 & 29,336 & 24,128 & 5,208 & 16,292 & 1,488 \\
2007 & 133,642 & 28,956 & 23,805 & 5,151 & 15,467 & 1,792 \\
2008 & 164,126 & 27,319 & 22,365 & 4,954 & 14,509 & 1,546 \\
2009 & 193,188 & 25,909 & 20,983 & 4,926 & 13,380 & 1,518 \\
2010 & 224,735 & 26,589 & 21,605 & 4,984 & 13,938 & 1,699 \\
2011 & 260,203 & 26,798 & 21,664 & 5,134 & 13,981 & 1,685 \\
2012 & 297,051 & 27,624 & 22,209 & 5,415 & 14,465 & 1,818 \\
2013 & 333,114 & 27,627 & 22,093 & 5,534 & 14,855 & 1,962 \\
2014 & 372,055 & 28,559 & 22,727 & 5,832 & 15,672 & 1,782 \\
2015 & 410,432 & 30,185 & 23,758 & 6,427 & 16,982 & 1,698 \\
2016 & 450,183 & 31,025 & 24,133 & 6,892 & 17,868 & \\
\hline
\end{tabular}

Table 6. Continue.

\begin{tabular}{llllll}
\hline & \multicolumn{3}{l}{ Persons of effective employment permit } & & \\
\cline { 2 - 5 } End of year & Categories of Work & & & \\
\cline { 2 - 5 } & $\begin{array}{l}\text { Full-time teacher teaching courses on } \\
\text { foreign languages at a short-term class } \\
\text { registered for supplementary schooling }\end{array}$ & Execute bond & School Teacher & $\begin{array}{l}\text { Director of a business invested } \\
\text { in or set up by overseas } \\
\text { Chinese or foreigner(s) }\end{array}$ & $\begin{array}{l}\text { Sports coach } \\
\text { and athlete }\end{array}$ \\
\hline 2004 & 5,934 & - & 1,604 & 633 & 41 \\
2005 & 6,630 & 1,537 & 2,061 & 1,044 & 27 \\
2006 & 6,392 & 1,465 & 2,212 & 1,440 & 47 \\
2007 & 5,983 & 1,981 & 2,243 & 1,451 & 39 \\
2008 & 5,839 & 1,575 & 2,356 & 1,452 & 42 \\
2009 & 5,841 & 1,241 & 2,375 & 1,503 & 51 \\
2010 & 5,640 & 1,376 & 2,397 & 1,503 & 36 \\
2011 & 5,715 & 1,327 & 2,406 & 1,644 & 40 \\
2012 & 5,615 & 1,269 & 2,445 & 1,853 & 29 \\
2013 & 5,094 & 1,403 & 2,408 & 2,010 & 39 \\
2014 & 5,040 & 1,342 & 2,291 & 2,207 & 45 \\
2015 & 5,000 & 1,719 & 2,299 & 2,357 & 46 \\
2016 & 4,875 & 1,750 & 2,254 & 2,530 & 50 \\
\hline
\end{tabular}

Source: Workforce Development Agency, Ministry of Labor (MOL) of Executive Yuan

Unit: Person-case

Table 7. Foreign Workers for Special Professions or Technical Assignments by Permit Authority Agency and Nationality in Taiwan, End of Dec., 2016.

\begin{tabular}{|c|c|c|c|}
\hline Item & Accumulation of application & $\begin{array}{l}\text { Accumulation of the employment } \\
\text { permit }\end{array}$ & $\begin{array}{l}\text { Persons of effective employment } \\
\text { permit }\end{array}$ \\
\hline Grand total & 467,464 & 450,183 & 31,025 \\
\hline By Permit Authority Agency & - & - & - \\
\hline Ministry of Labor & 458,055 & 440,824 & 29,556 \\
\hline Export Processing Zones & 2,130 & 2,113 & 492 \\
\hline Science Parks & 7,279 & 7,246 & 977 \\
\hline By Nationality & - & - & - \\
\hline Japan & 107,281 & 104,819 & 8,575 \\
\hline United States & 78,766 & 76,201 & 5,251 \\
\hline Canada & 30,136 & 29,074 & 1,042 \\
\hline United Kingdom & 22,928 & 22,325 & 1,033 \\
\hline South Africa & 12,987 & 12,513 & 595 \\
\hline Philippines & 18,725 & 18,034 & 1,505 \\
\hline Malaysia & 19,761 & 18,247 & 2,684 \\
\hline Korea, R.O. & 15,919 & 15,222 & 1,083 \\
\hline Australia & 8,699 & 8,400 & 404 \\
\hline Thailand & 9,625 & 8,960 & 283 \\
\hline India, R.O. & 12,512 & 11,982 & 1,458 \\
\hline Germany & 12,936 & 12,662 & 411 \\
\hline
\end{tabular}




\begin{tabular}{llll}
\hline Item & Accumulation of application & $\begin{array}{l}\text { Accumulation of the employment } \\
\text { permit }\end{array}$ & $\begin{array}{l}\text { Persons of effective employment } \\
\text { permit }\end{array}$ \\
\hline Russia & 11,494 & 11,266 & 279 \\
Indonesia & 8,103 & 7,745 & 845 \\
France & 9,390 & 9,065 & 554 \\
Singapore & 7,119 & 6,748 & 505 \\
Hong Kong & 11,346 & 10,582 & 941 \\
Ukraine & 5,515 & 5,266 & 233 \\
New Zealand & 3,680 & 3,561 & 135 \\
Vietnam & 4,281 & 3,869 & 516 \\
Others & 56,261 & 53,642 & 2,693 \\
\hline
\end{tabular}

Source: Workforce Development Agency, Ministry of Labor (MOL) of Executive Yuan

Unit: Person-case

\subsection{Flexible Labour Markets}

The global financial crisis put an end to the Taiwan boom as unemployment again reached over 5 per cent in 2009. The government made large investments into active labour market policies such as job placement services and training programmes. Expansionary monetary policy boosted domestic demand, notably in construction, and played a decisive role in Taiwan's success in reducing unemployment. Recent years have shown a sustained interest in work flexibility, and legislators appear to have directed their attention to flexible work issues. The government promoted a cheap and flexible workforce, which created a favourable environment for foreign capital in search of investment opportunities and a way into the world markets.

Over the course of the period 1978 to 2016, the labor force participation rate keeps the same, 58.00. But, the unemployment rate grows from from 1.67 in 1978 to 5.88 in 2009, then 3.92 in 2016, which is shown in Table 8. According to employed persons by industry, the rate of goods-producing industries tends to account for 35.88 per cent of employment, and services-producing industries for around 59.17 per cent in 2016. Low-technology industries (which includes subsectors such as agriculture, forestry, fishing and animal husbandry, manufacture of food, textiles, furniture) had a negative contribution to employment. High-technology industries (which includes subsectors such as production of chemicals, cars, electrical equipment or computers) had a small contribution to the expansion of the highest layers of employment, and an important contribution to the expansion of the middle layers. The industrial sector was the driver of the middle (and mid-low) segments of employment. Knowledge-intensive services (which includes information \& communication, professional, scientific \& technical activities, and other activities) are biased upwards, whereas less knowledge-intensive services (which includes retail, hotels and restaurants and land transport among other activities) show the opposite image, biased downwards.

Table 8. Important Indicators Based on Manpower Survey Results in Taiwan, End of 1978-2016.

\begin{tabular}{|c|c|c|c|c|c|c|}
\hline \multirow{2}{*}{ Year } & \multirow{2}{*}{ Civilian Population aged 15 years \& over } & \multicolumn{3}{|c|}{ Labor Force } & \multirow{2}{*}{$\begin{array}{l}\text { Not in labor } \\
\text { force }\end{array}$} & \multirow{2}{*}{$\begin{array}{l}\text { Labor force participation } \\
\text { rate }\end{array}$} \\
\hline & & Total & Employed & Unemployed & & \\
\hline 1978 & 10784 & 6337 & 6231 & 106 & 4448 & 58.76 \\
\hline 1980 & 11378 & 6629 & 6547 & 82 & 4749 & 58.26 \\
\hline 1990 & 14219 & 8423 & 8283 & 140 & 5795 & 59.24 \\
\hline 2000 & 16963 & 9784 & 9491 & 293 & 7178 & 57.68 \\
\hline 2008 & 18623 & 10853 & 10403 & 450 & 7770 & 58.28 \\
\hline 2009 & 18855 & 10917 & 10279 & 639 & 7937 & 57.90 \\
\hline 2011 & 19253 & 11200 & 10709 & 491 & 8053 & 58.17 \\
\hline 2012 & 19436 & 11341 & 10860 & 481 & 8096 & 58.35 \\
\hline 2013 & 19587 & 11445 & 10967 & 478 & 8142 & 58.43 \\
\hline 2014 & 19705 & 11535 & 11079 & 457 & 8170 & 58.54 \\
\hline 2015 & 19842 & 11638 & 11198 & 440 & 8204 & 58.65 \\
\hline 2016 & 19962 & 11727 & 11267 & 460 & 8235 & 58.75 \\
\hline
\end{tabular}

Table 8. Continue.

\begin{tabular}{|c|c|c|c|c|}
\hline \multirow[b]{2}{*}{ Year } & \multirow[b]{2}{*}{ Unemployment rate } & \multicolumn{3}{|l|}{ Employed Persons by Industry } \\
\hline & & Agriculture, forestry, fishing and animal husbandry & $\begin{array}{l}\text { Goods- producing } \\
\text { industries }\end{array}$ & $\begin{array}{l}\text { Services-producing } \\
\text { industries }\end{array}$ \\
\hline 1978 & 1.67 & - & - & - \\
\hline 1980 & 1.23 & - & - & - \\
\hline 1990 & 1.67 & - & - & - \\
\hline 2000 & 2.99 & - & - & - \\
\hline 2008 & 4.14 & - & - & - \\
\hline 2009 & 5.85 & - & - & - \\
\hline 2011 & 4.39 & 5.06 & 36.34 & 58.60 \\
\hline 2012 & 4.24 & 5.01 & 36.23 & 58.75 \\
\hline
\end{tabular}




\begin{tabular}{lllll}
\hline \multirow{2}{*}{ Year } & Unemployment rate & Employed Persons by Industry & & \\
\cline { 3 - 5 } & & Agriculture, forestry, fishing and animal husbandry & $\begin{array}{l}\text { Goods- producing } \\
\text { industries }\end{array}$ & $\begin{array}{l}\text { Services-producing } \\
\text { industries }\end{array}$ \\
\hline 2013 & 4.18 & 4.96 & 36.16 & 58.89 \\
2014 & 3.96 & 4.95 & 36.14 & 58.91 \\
2015 & 3.78 & 4.95 & 36.03 & 59.02 \\
2016 & 3.92 & 4.95 & 35.88 & 59.17 \\
\hline
\end{tabular}

Source: Directorate General of Budget, Accounting and Statistics (DGBAS) of Executive Yuan, R.O.C.

Unit: Thousand Persons, \%

\subsection{Employment Structure}

Taiwan embraces the neoliberal policies of free trade and deregulated markets, and the Taiwan economic development has been its increasing economic openness to global capital. It does this by implementing a series of policies that would create a financial and economic environment more conducive to capital mobility and labour flows. Industries like textiles and clothing were decreasing and disappearing, while upcoming economic branches like banking and insurance, transport, and retail trade were hiring growing numbers of employees. Taiwan with an upgrading pattern of employment growth with little expansion in the bottom quintile experienced low levels of job growth in the middle. Slow growth in the middle raises concerns about the structure of opportunities in an economy. One of the worries about economies is that they do not produce sufficient middle-wage jobs to support the maintenance of the large middle class. Opportunities for social mobility may be diminished in employment structures with growth only at the ends of the wage distribution. The middle-quintile jobs are the solid manufacturing and office jobs that enabled people to achieve decent pay and a middle-class standard of living. The employment expansions in Taiwan shared some features which were higher growth in high-paid jobs, relatively lower growth in middle-paid jobs and in lower-paid jobs. The declining middle or the hollowing out of the labour market appears to have been somewhat sharper.

Between 2008 and 2009, the total number (Unit: Thousand Persons) of employed persons declines from 10,403 in 2008 to 10,279 in 2009 , and the number of the paid employees declines from 7,902 in 2008 to 7,889 in 2009, as a result of the economic crisis in Taiwan. By employed persons of privatepaid- employees, the number decreases from 6,945 in 2008 to 6,850 in 2009 , but by employed persons of government - paidemployees, the number develops from 958 in 2008 to 1,040 in 2009, which is shown in Table 9. Employment growth in government or public administration is greater during periods of recession than in periods of economic growth. This in some degree reflects government efforts to counter the downturn in economic activity through increased public expenditure.

Table 9. Employed Persons by Class of Worker in Taiwan, End of 1978-2016.

\begin{tabular}{|c|c|c|c|c|c|c|c|}
\hline \multirow{2}{*}{ Year } & \multirow{2}{*}{ Total } & \multirow{2}{*}{ Employers } & \multirow{2}{*}{$\begin{array}{l}\text { Own-account } \\
\text { workers }\end{array}$} & \multirow{2}{*}{$\begin{array}{l}\text { Unpaid family } \\
\text { workers }\end{array}$} & \multicolumn{3}{|c|}{ Paid employees } \\
\hline & & & & & Subtotal & Private & Government \\
\hline 1978 & 6231 & 197 & 1374 & 775 & 3885 & 3141 & 744 \\
\hline 1980 & 6547 & 290 & 1341 & 701 & 4216 & 3400 & 815 \\
\hline 1990 & 8283 & 399 & 1543 & 744 & 5597 & 4641 & 956 \\
\hline 2000 & 9491 & 513 & 1523 & 710 & 6746 & 5790 & 955 \\
\hline 2008 & 10403 & 508 & 1374 & 619 & 7902 & 6945 & 958 \\
\hline 2009 & 10279 & 470 & 1331 & 588 & 7889 & 6850 & 1040 \\
\hline 2012 & 10860 & 476 & 1319 & 570 & 8495 & 7468 & 1027 \\
\hline 2013 & 10967 & 468 & 1317 & 567 & 8615 & 7595 & 1020 \\
\hline 2014 & 11079 & 458 & 1310 & 573 & 8737 & 7714 & 1023 \\
\hline 2015 & 11198 & 451 & 1313 & 574 & 8860 & 7836 & 1024 \\
\hline 2016 & 11267 & 445 & 1319 & 576 & 8926 & 7901 & 1025 \\
\hline
\end{tabular}

Source: Directorate General of Budget, Accounting and Statistics (DGBAS) of Executive Yuan, R.O.C.

Unit: Thousand Persons

The growing service sectors were polarized between the top and bottom of the jobs structure in Taiwan. According to employed persons by occupation, the priorities of the number are follows: "Craft \& machine operation related workers", "Service \& sales workers", "Technicians \& associate professionals", "Professionals", "Clerical support workers", "Skilled agricultural, forestry and fishery Workers", "Legislators, senior officials \& managers", which is shown in Table 10. It shows the top-heavy growth in knowledge-intensive services and decline at the bottom in low-skill services, illustrating the polarizing pressures in the
Taiwan labour market. Knowledge-intensive services accounted for 50 per cent of growth in the top quintile, such as occupation"Professionals" (from 732 in 2001 to 1,389 in 2016, 190 per cent of growth), and "Technicians \& associate professionals" (from 1,450 in 2001 to 2,029 in 2016, 40 per cent of growth). Low-skill service jobs make up 20 per cent of growth in the bottom quintile, such as occupation "Clerical support workers" (from 1,001 in 2001 to 1,257 in 2016, 26 per cent of growth), "Service \& sales workers" (from 1,828 in 2001 to 2,206 in 2016, 21 per cent of growth), and "Craft \& machine operation related workers" (from 3,292 in 2001 to 
3,506 in 2016, 7 per cent of growth). It shows the top-heavy growth in knowledge-intensive services and shows the

slight-growth at the bottom in low-skill services, illustrating the polarizing pressures in the Taiwan labour market.

Table 10. Employed Persons by Occupation in Taiwan, End of 2001-2016.

\begin{tabular}{|c|c|c|c|c|c|c|c|c|}
\hline Year & Total & $\begin{array}{l}\text { Legislators, } \\
\text { senior officials } \\
\text { \& managers }\end{array}$ & Professionals & $\begin{array}{l}\text { Technicians } \\
\text { \& associate } \\
\text { professionals }\end{array}$ & $\begin{array}{l}\text { Clerical } \\
\text { support } \\
\text { workers }\end{array}$ & $\begin{array}{l}\text { Service \& sales } \\
\text { workers }\end{array}$ & $\begin{array}{l}\text { Skilled agricultural, } \\
\text { forestry and fishery } \\
\text { Workers }\end{array}$ & $\begin{array}{l}\text { Craft \& machine } \\
\text { operation related } \\
\text { workers }\end{array}$ \\
\hline 2001 & 9383 & 405 & 732 & 1450 & 1001 & 1828 & 675 & 3292 \\
\hline 2008 & 10403 & 463 & 1098 & 1921 & 1076 & 2040 & 500 & 3305 \\
\hline 2009 & 10279 & 444 & 1100 & 1977 & 1088 & 2014 & 506 & 3149 \\
\hline 2011 & 10709 & 435 & 1195 & 1957 & 1188 & 2086 & 496 & 3352 \\
\hline 2012 & 10860 & 422 & 1244 & 1950 & 1222 & 2119 & 495 & 3408 \\
\hline 2014 & 11079 & 394 & 1333 & 1990 & 1244 & 2166 & 492 & 3459 \\
\hline 2015 & 11198 & 387 & 1370 & 2019 & 1248 & 2181 & 496 & 3496 \\
\hline 2016 & 11267 & 381 & 1389 & 2029 & 1257 & 2206 & 500 & 3506 \\
\hline
\end{tabular}

Source: Directorate General of Budget, Accounting and Statistics (DGBAS) of Executive Yuan, R.O.C.

Unit: Thousand Persons

The fate of the less knowledge- intensive service sector will be important to understand variation in job polarization. The institutions that regulate the low-wage labour market will be important for understanding variability in service job growth. Unless some low-skill service jobs begin to upgrade, growth in the middle of the jobs structure will be increasingly affected by the cycles of boom. Economic restructuring altered the employment structure in Taiwan. The striking feature of economic restructuring has been the decline of middle-wage jobs, driven by the collapse of manufacturing employment. This pattern of change has raised the spectre of a transition to an hourglass economy, where job growth is concentrated at the top and the bottom of the wage structure but not in the middle. The poor growth of middle-wage jobs is worrying because these jobs were crucial to the expansion of the middle class, and its decline may contribute to worsening prospects for social mobility.

\subsection{Human-Capital}

Taiwan has not only experienced rapid technological change, but also undergone a process of massive educational reform. Changes in education began during the 1980s when the government initiated a modernizing project based on the marketization of education delivery. The centrality of education is seen as the driver of economic growth in the context of globalization. Government policy has emphasized raising the number of school leavers continuing in higher education or the opening of tertiary education to larger sections of the population. The policy goal of widening participation, that is "increasing the numbers of undergraduates from lower socio-economic groups", has been achieved in part. The young graduates expressed feelings of uncertainty as they entered a new life-course phase from education to work. This is especially pertinent in Taiwan, given emphasis on the expansion of higher education and the growing disparity between graduates (highly qualified and skilled) and non-graduates (poorly qualified and low-skilled) in their experiences of career transitions and trajectories. Having university degrees would enable them to have more choices in employment.

According to educational attainment of labor force participation, the rates develop in these educational phases: "Senior high" (from 47.39 in 1978 to 50.41 in 2016), "Vocational" (from 59.39 in 1978 to 67.48 in 2016), "Junior college" (from 67.46 in 1978 to 74.04 in 2016), "University \& graduate school" (from 59.65 in 1978 to 64.53 in 2016), which is shown in Table 11; but the rates decline in these educational phases: "Primary school \& below" (from 57.25 in 1978 to 25.31 in 2016), "Junior high" (from 67.45 in 1978 to 60.00 in 2016). Over the last three decades, the proportion of the labour force with tertiary education increased by 11.46 percentage points or more in Taiwan. The proportion of workers without upper secondary schooling declines everywhere. The proportion of highly educated workers has increased, while numbers of mid- and lowly educated workers have declined.

Table 11. Labor Force Participation Rate by Educational Attainment in Taiwan, End of 1978-2016.

\begin{tabular}{|c|c|c|c|c|c|c|c|c|c|}
\hline \multirow[b]{2}{*}{ Year } & \multirow[b]{2}{*}{ Total } & \multirow[b]{2}{*}{ Male } & \multirow[b]{2}{*}{ Female } & \multicolumn{6}{|c|}{ Educational attainment } \\
\hline & & & & $\begin{array}{l}\text { Primary school \& } \\
\text { below }\end{array}$ & Junior high & Senior high & Vocational & $\begin{array}{l}\text { Junior } \\
\text { college }\end{array}$ & $\begin{array}{l}\text { University \& } \\
\text { graduate school }\end{array}$ \\
\hline 1978 & 58.76 & 77.96 & 39.13 & 57.25 & 67.45 & 47.39 & 59.39 & 67.46 & 59.65 \\
\hline 1980 & 58.26 & 77.11 & 39.25 & 55.47 & 68.29 & 47.51 & 60.24 & 68.50 & 59.96 \\
\hline 1990 & 59.24 & 73.96 & 44.50 & 51.86 & 67.24 & 52.04 & 64.68 & 70.06 & 62.24 \\
\hline 2000 & 57.68 & 69.42 & 46.02 & 39.58 & 64.62 & 51.75 & 65.67 & 73.29 & 61.44 \\
\hline 2008 & 58.28 & 67.09 & 49.67 & 29.71 & 61.99 & 50.57 & 69.31 & 77.47 & 62.63 \\
\hline 2011 & 58.17 & 66.67 & 49.97 & 27.40 & 60.56 & 49.62 & 68.05 & 76.28 & 64.13 \\
\hline 2012 & 58.35 & 66.83 & 50.19 & 27.36 & 60.51 & 49.62 & 68.04 & 75.51 & 64.35 \\
\hline 2013 & 58.43 & 66.74 & 50.46 & 27.23 & 61.04 & 48.79 & 67.80 & 74.92 & 64.44 \\
\hline 2014 & 58.54 & 66.78 & 50.64 & 25.79 & 60.64 & 49.16 & 67.68 & 74.52 & 65.14 \\
\hline
\end{tabular}




\begin{tabular}{lllllllll}
\hline \multirow{2}{*}{ Year } & Total & Male & Female & \multicolumn{2}{l}{ Educational attainment } \\
\cline { 5 - 8 } & & & $\begin{array}{l}\text { Primary school \& } \\
\text { below }\end{array}$ & Junior high & Senior high & Vocational & $\begin{array}{l}\text { Junior } \\
\text { college }\end{array}$ & $\begin{array}{l}\text { University \& } \\
\text { graduate school }\end{array}$ \\
\hline 2015 & 58.65 & 66.91 & 50.74 & 25.36 & 59.89 & 49.92 & 67.69 \\
2016 & 58.75 & 67.05 & 50.80 & 25.31 & 60.00 & 50.41 & 67.48 & 74.02 \\
\hline
\end{tabular}

Source: Directorate General of Budget, Accounting and Statistics (DGBAS) of Executive Yuan, R.O.C.

Unit: Thousand Persons, \%

The total rate of unemployment in Taiwan develops from 1.67 in 1978 to 3.92 in 2016, which is shown in Table 12. According to educational attainment of unemployment, the rates develop in these educational phases: "Primary school \& below" (from 0.64 in 1978 to 2.31 in 2016), "Junior high" (from 2.28 in 1978 to 3.52 in 2016), "Senior high" (from 3.72 in 1978 to 3.99 in 2016), "Vocational" (from 3.67 in 1978 to 3.87 in 2016), "University \& graduate school" (from 2.54 in 1978 to 4.84 in 2016); but the rate declines in the educational phases: "Junior college" (from 3.75 in 1978 to 2.91 in 2016).
Over the last three decades Taiwan created a disproportionate share of jobs in the high-paid occupations that require high levels of education, whereas the numerical importance of occupations with low levels of education has declined. Lowly educated unemployment is particularly sensitive to economic fluctuations and the labour market situation. Cyclical unemployment becomes increasingly persistent as the recessions of the late 2008 and early 2009 increased the numbers of long-term unemployed.

Table 12. Unemployment Rate by Educational Attainment in Taiwan, End of 1978-2016.

\begin{tabular}{|c|c|c|c|c|c|c|c|c|c|}
\hline \multirow[b]{2}{*}{ Year } & \multirow[b]{2}{*}{ Total } & \multirow[b]{2}{*}{ Male } & \multirow[b]{2}{*}{ Female } & \multicolumn{6}{|c|}{ Educational attainment } \\
\hline & & & & $\begin{array}{l}\text { Primary school \& } \\
\text { below }\end{array}$ & Junior high & Senior high & Vocational & $\begin{array}{l}\text { Junior } \\
\text { college }\end{array}$ & $\begin{array}{l}\text { University \& } \\
\text { graduate school }\end{array}$ \\
\hline 1978 & 1.67 & 1.57 & 1.86 & 0.64 & 2.28 & 3.72 & 3.67 & 3.75 & 2.54 \\
\hline 1980 & 1.23 & 1.11 & 1.47 & 0.40 & 1.45 & 2.31 & 2.79 & 2.51 & 1.93 \\
\hline 1990 & 1.67 & 1.68 & 1.64 & 0.58 & 1.73 & 2.38 & 2.55 & 2.46 & 2.03 \\
\hline 2000 & 2.99 & 3.36 & 2.44 & 2.05 & 3.50 & 2.96 & 3.48 & 2.90 & 2.67 \\
\hline 2008 & 4.14 & 4.39 & 3.83 & 2.66 & 4.52 & 4.36 & 4.33 & 3.44 & 4.78 \\
\hline 2011 & 4.39 & 4.71 & 3.96 & 2.52 & 4.44 & 4.75 & 4.63 & 3.40 & 5.18 \\
\hline 2012 & 4.24 & 4.49 & 3.92 & 2.32 & 4.27 & 4.45 & 4.15 & 3.18 & 5.37 \\
\hline 2013 & 4.18 & 4.47 & 3.80 & 2.29 & 4.29 & 4.25 & 4.06 & 3.11 & 5.26 \\
\hline 2014 & 3.96 & 4.27 & 3.56 & 2.04 & 3.87 & 3.79 & 3.85 & 3.09 & 4.99 \\
\hline 2015 & 3.78 & 4.05 & 3.44 & 1.84 & 3.29 & 3.80 & 3.84 & 2.75 & 4.79 \\
\hline 2016 & 3.92 & 4.19 & 3.57 & 2.31 & 3.52 & 3.99 & 3.87 & 2.91 & 4.84 \\
\hline
\end{tabular}

Source: Directorate General of Budget, Accounting and Statistics (DGBAS) of Executive Yuan, R.O.C.

Unit:\%

The process of rising levels of educational achievement continues for the last three decades. This is shown by Table 13, which depicts the share of education attainment of population aged 15 and above in Taiwan. The educational level of the working population has substantially increased in Taiwan since the 1980s. By school-life expectancy of aged 6(year), the average workers' education increased from 14.6 in 2002 to 16.5 in 2012. Changes in the Taiwan labour market have created flexibilization winners and losers, especially along the lines of human capital endowment. The expansion of higher education has been accompanied by an increase in the types of skilled and professional occupations. This suggests that in the race between education and technology, labour supply driven by rising educational attainment has kept pace with labour demand shaped by continuous technical change.

Table 13. Education attainment of population aged 15 and above in Taiwan, End of 1998-2013.

\begin{tabular}{|c|c|c|c|c|}
\hline Year & $\begin{array}{l}\text { Junior high school and below } \\
(\%)\end{array}$ & $\begin{array}{l}\text { Senior high school and Vocational } \\
\text { school }(\%)\end{array}$ & $\begin{array}{l}\text { Junior college and above } \\
(\%)\end{array}$ & $\begin{array}{l}\text { School-life expectancy of } \\
\text { aged 6(year) }\end{array}$ \\
\hline 1998 & 45.9 & 33.0 & 21.2 & - \\
\hline 1999 & 44.2 & 33.5 & 22.3 & - \\
\hline 2000 & 43.2 & 33.5 & 23.3 & - \\
\hline 2001 & 41.8 & 33.7 & 24.5 & - \\
\hline 2002 & 40.2 & 33.8 & 26.0 & 14.6 \\
\hline 2003 & 38.9 & 33.7 & 27.4 & 15.0 \\
\hline 2005 & 36.6 & 33.2 & 30.2 & 15.6 \\
\hline 2006 & 35.5 & 32.9 & 31.6 & 15.7 \\
\hline 2007 & 34.4 & 32.7 & 32.9 & 16.1 \\
\hline 2008 & 33.3 & 32.3 & 34.3 & 16.1 \\
\hline 2009 & 32.3 & 32.1 & 35.6 & 16.0 \\
\hline 2010 & 31.3 & 32.0 & 36.8 & 16.2 \\
\hline
\end{tabular}




\begin{tabular}{|c|c|c|c|c|}
\hline Year & $\begin{array}{l}\text { Junior high school and below } \\
(\%)\end{array}$ & $\begin{array}{l}\text { Senior high school and Vocational } \\
\text { school }(\%)\end{array}$ & $\begin{array}{l}\text { Junior college and above } \\
(\%)\end{array}$ & $\begin{array}{l}\text { School-life expectancy of } \\
\text { aged 6(year) }\end{array}$ \\
\hline 2011 & 30.3 & 31.8 & 37.9 & 16.3 \\
\hline 2012 & 29.3 & 31.7 & 39.0 & 16.5 \\
\hline 2013 & 28.4 & 31.5 & 40.1 & 16.3 \\
\hline
\end{tabular}

Source: Directorate General of Budget, Accounting and Statistics (DGBAS) of Executive Yuan, R.O.C.

Unit: \%, year

\section{Discussion}

In a globalized economy, capital and labour are increasingly mobile and these have led to an intensification of competition. During recessions the burden of economic adjustment is shifted to lower educated workers, and firms tend to dismiss low qualified workers. Those with lower education have been considered as a rather marginal workforce and have become highly flexibilized. There will be an increase in the numbers of workers who will be trapped in an insecure or sub-protected position: part-time workers or atypical workers. Welfare states are expected to help non-working people back into employment, and to provide social services for an ageing society. These employment relationships contribute to the social integration of large parts of the population by integrating them in the labour market. The status of the employment relationship is an important source of individual social security and social participation. But, neither the recent labour market reforms, nor the state unemployment protection schemes, provide a sufficient level of social security. Adapting unemployment protection to labour market change represents a major social and economic challenge for welfare states. The local communities, Taiwan should opt for preventing the rise in inequality through institutional rules.

As the risk of fixed-term employment has increased among young people, gaining a foothold in the labour market has become increasingly difficult for them. The ubiquity of uncertainty and risk has turned industrial societies into risk societies, and employment risks become generalized at all levels of society. Social inequalities will increase because uncertainties will lead employers to increasingly shift labour market risks on to less powerful employees. Individuals with fewer human capital resources come to face a greater risk of experiencing labour market exclusion, thus raising their poverty risk. Unequal educational outcomes are the cause of social problems, and social policy can play a preventive role by investing in people's skills. A form of security provision is when individuals insure against future labour-market risk by investing in their own educational opportunities to anticipate future adverse labour-market change. The educational qualifications and occupational class are increasingly important for young people.

\section{Conclusions}

The social and human context within knowledge is dynamic and complex in the local communities. Careers are no longer something predictable but rather something more boundaryless. The knowledge economy emphasizes the importance of human capital in generating wealth. Intelligent enterprise is presented as a new paradigm to build sustainable competitive advantages. The local communities, Taiwan with legislation to attract highly skilled migrants, and with measures to ease the entry and boost the employment and entrepreneurial opportunities of overseas students, is one of the best places to benefit from the global talent pool. Taiwan should be willing to open its borders to the movement of people, and should provide infrastructure for support so that all can work to benefit from trade. Education comes to be a means to accumulate the social and cultural capital required to be competitive in increasingly globalized professional contexts. The internationalization of education becomes a vehicle for the preparation of students to compete in a global marketplace.

The 2000s was a period of slow growth and economic restructuring, with unemployment rising fast as numbers of workers were made redundant from traditional industries. The chances of a smooth transition into work life after leaving the education system have dropped. A large amount of education system leavers have to face a period of unemployment after graduation. The risk of entering the labour market by taking up a fixed-term job has increased over the last few decades. Employment and life-course trajectories no longer follow stable long-term pathways, but take the form of unstable and contingent patchwork careers. Taiwan has implemented variable strategies when adapting its economies and labour markets to the increasing flexibilization demands. This strategy of labour flexibility has brought about an increase of labour precariousness. Such precariousness is understood as a loss of job quality not only in terms of temporality but also in other dimensions: economical (low wages), social (atypical job), security and access to social protection. The activation strategy might promote social inclusion and participation. Taiwan should make the adjustment of social security schemes and infrastructure to the needs of people in various life circumstances.

Domestic labor shortages due to brain drains, inadequate natives with requisite qualifications, aging, or declines in the population stimulate employers' demands to access global talent. Student mobility and corporate mobility will lead to a more mobile global labour market and an internationally mobile elite. The increasingly globalized natures of both the labour and education markets are the social consequences of how market-driven forces have intertwined the mobilities of globalized flows of workers. Such practices have changed the social-political settings of workers' daily lives. Opportunities for the higher qualified to convert their precarious employment situation into a stable one are much higher, while especially low-qualified young adults are increasingly stuck in 
precarious forms of employment. The situation of young labour market entrants, has been further worsened by selective employment deregulation which has caused a dramatic increase in employment risks. Policy for youth unemployed took a step towards strengthening investment in human capital. Taiwan should be interested in improving its access to highskilled migrants and implement policies to facilitate this objective.

\section{References}

[1] Barbieri Paolo (2011). Italy: No Country for Young Men (and Women): The Italian Way of Coping with Increasing Demands for Labour Market Flexibility and Rising Welfare Problems. In Hans-Peter Blossfeld, Sandra Buchholz, Dirk Hofäcker, Kathrin Kolb, and Gosta Esping-Andersen(ed.), Globalized Labour Markets and Social Inequality in Europe (108-148). Palgrave Macmillan. ISBN 9780230241992.

[2] Buchholz Sandra, Kolb Kathrin, Hofäcker Dirk, and Blossfeld Hans-Peter (2011). Globalized Labour Markets and Social Inequality in Europe: Theoretical Framework. In Hans-Peter Blossfeld, Sandra Buchholz, Dirk Hofäcker, Kathrin Kolb, and Gosta Esping-Andersen(ed.), Globalized Labour Markets and Social Inequality in Europe (3-22). Palgrave Macmillan. ISBN 9780230241992 .

[3] Duncan Natasha T. (2012). Immigration Policymaking in the Global Era. In Pursuit of Global Talent. Palgrave Macmillan. ISBN: 9781137048967.

[4] Eichhorst Werner, Konle-Seidl Regina, Koslowski Alison and Marx Paul (2011). Quantity over quality? A European comparison of the changing nature of transitions between non-employment and employment. In Jochen Clasen and Daniel Clegg(ed.), Regulating the risk of unemployment: national adaptations to post-industrial labour markets in Europe (1-20). Oxford: Oxford University Press. ISBN-13: 9780199592296.

[5] Green Anne and Skeldon Ronald (2013). Shifting Categories of Belonging in the United Kingdom Census: Changing Definitions of Migration, Labour-Market Access and Experience. In Ludger Pries(ed.), Shifting Boundaries of Belonging and New Migration Dynamics in Europe and China (107-135). Palgrave Macmillan. ISBN: 9780230369726.

[6] Hofäcker Dirk, Buchholz Sandra, Kolb Kathrin, and Blossfeld Hans-Peter (2011). The Flexibilization of European Labour Markets and the Development of Social Inequalities: Comparing Evidence from Nine Globalized Countries. In Hans-Peter Blossfeld, Sandra Buchholz, Dirk Hofäcker, Kathrin Kolb, and Gosta Esping-Andersen(ed.), Globalized Labour Markets and Social Inequality in Europe (295-322). Palgrave Macmillan. ISBN 9780230241992.

[7] Koch Michael (2013). The Use of Flexible Working across National Contexts and its Relationship to Organizational Performance. In Emma Parry, Eleni Stavrou and Mila Lazarova(ed.), Global Trends in Human Resource Management (237-256). Palgrave Macmillan. ISBN: 9780230354838 .

[8] Marti José Maria Viedma and Cabrita Maria do Rosário (2012). Entrepreneurial Excellence in the Knowledge Economy. Intellectual Capital Benchmarking Systems. Palgrave Macmillan. ISBN: 9781137024077.
[9] Prelipcean Radu Daniel, Islam Mir Nazmul, Peebles Andrea, Barakat Thomas and Yao Jianming (2014). The Impact of Public Sector Entrepreneurship in International Education on Skilled Migration. A Comparative Analysis of Canadian and Australian International Education. In Alexander W. Wiseman(ed.), International educational innovation and public sector entrepreneurship (125-156). International Perspectives on Education and Society, Volume 23. merald Group Publishing Limited. ISBN: 9781781907085.

[10] Purcell Christina, Flynn Matt, and Ayudhya Uracha Chatrakul $\mathrm{Na}$ (2011). The Effects of Flexibilization on Social Divisions and Career Trajectories in the UK Labour Market. In Hans-Peter Blossfeld, Sandra Buchholz, Dirk Hofäcker, Kathrin Kolb, and Gosta Esping-Andersen(ed.), Globalized Labour Markets and Social Inequality in Europe (261-294). Palgrave Macmillan. ISBN 9780230241992.

[11] Sousa Joa o-Paulo Bola (2011). The Changing Character of Small Town Ontario: Transnational Capital/Labour Flows in a Notso-Globalized-World. In Alessandro Bonanno, Josefa Salete Barbosa Cavalcanti(ed.), Globalization and the time-space reorganization: capital mobility in agriculture and food in the Americans. Research in Rural Sociology and Development, Volume 17 (109-145). Bingley, U.K.: Emerald. ISBN: 9780857243171.

[12] Triandafyllidou Anna (2013A). Circular Migration: Introductory Remarks. In Anna Triandafyllidou(ed.), Circular Migration between Europe and its Neighbourhood: Choice or Necessity? (1-19). Oxford: Oxford University Press. ISBN-13: 9780199674510 .

[13] Tridico Pasquale (2011). Institutions, Human Development and Economic Growth in Transition Economies. Palgrave Macmillan. ISBN: 9780230240681 hardback.

[14] Wejnert Barbara (2013). Reflections on the Impact of Globalization: Diffusion, Equality, and Opportunitits. In Barbara Wejnert(ed.), Voices of Globalization. Research in Political Sociology, Volume 21, 255-261. Emerald Group Publishing Limited. ISBN: 9781781905456.

[15] Alas Ruth and Vanhala Sinikka (2013). Converging and Diverging Trends in HRM between the Nordic Countries and Estonia. In Emma Parry, Eleni Stavrou and Mila Lazarova(ed.), Global Trends in Human Resource Management (122-146). Palgrave Macmillan. ISBN: 9780230354838.

[16] Baxter Aryn, Chapman David W., DeJaeghere Joan, Pekol Amy R. and Weiss Tamara (2014). Youth Entrepreneurship Education and Training for Poverty Alleviation: A Review of International Literature and Local Experiences. In Alexander W. Wiseman(ed.), International educational innovation and public sector entrepreneurship (33-58). International Perspectives on Education and Society, Volume 23. merald Group Publishing Limited. ISBN: 9781781907085.

[17] Bowler Rick (2013). The Risky Business of Challenging Risk: Youth Work and Young People through the Lens of 'Race'. In Jeremy Kearney and Catherine Donovan(ed.), Constructing Risky Identities in Polickkly and Practice (146-162). Palgrave Macmillan. ISBN: 9781137276087.

[18] Chusseau Nathalie and Hellier Joël (2013). Education, Intergenerational Mobility and Inequality. In Joël Hellier and Nathalie Chusseau(ed.), Growing Income Inequalities. Economic Analyses (227-273). Palgrave Macmillan. ISBN: 9781137283306 . 
[19] Chusseau Nathalie, Hellier Joël and Ben-Halima B. (2013). Education, Intergenerational Mobility and Inequality. In Joël Hellier and Nathalie Chusseau(ed.), Growing Income Inequalities. Economic Analyses (227-273). Palgrave Macmillan. ISBN: 9781137283306.

[20] Dumont Michel (2013). Is there a Trade-off between Wage Inequality and Unemployment? In Joël Hellier and Nathalie Chusseau(ed.), Growing Income Inequalities. Economic Analyses (147-172). Palgrave Macmillan. ISBN: 9781137283306

[21] Gooderham Paul, Grøgaard Birgitte and Nordhaug Odd (2013). Divergent Norwegian and North American HRM Regimes: Implications for Norwegian MNEs. In Emma Parry, Eleni Stavrou and Mila Lazarova(ed.), Global Trends in Human Resource Management (163-178). Palgrave Macmillan. ISBN: 9780230354838 .

[22] Hellier Joël (2013). The North-South HOS Model, Inequality and Globalization. In Joël Hellier and Nathalie Chusseau(ed.), Growing Income Inequalities. Economic Analyses (107-146). Palgrave Macmillan. ISBN: 9781137283306.

[23] Hellier Joël and Lambrecht Stéphane (2013). Inequality, Growth and Welfare: The Main Links. In Joël Hellier and Nathalie Chusseau(ed.), Growing Income Inequalities. Economic Analyses (274-311). Palgrave Macmillan. ISBN: 9781137283306.

[24] Lazarova Mila, Mayrhofer Wolfgang and Brewster Chris (2013). 'Plus ça change, plus c'est la même chose': A Longitudinal Analysis of HRM Work and the Profile of Senior HR Managers. In Emma Parry, Eleni Stavrou and Mila Lazarova(ed.), Global Trends in Human Resource Management (11-34). Palgrave Macmillan. ISBN: 9780230354838 .

[25] Lindeberg Tina, Månson Bo and Larsen Henrik Holt (2013). HRM in Scandinavia - Embedded in the Scandinavian Model? In Emma Parry, Eleni Stavrou and Mila Lazarova(ed.), Global Trends in Human Resource Management (147-162). Palgrave Macmillan. ISBN: 9780230354838.

[26] Mahendran Kesi (2013). A Two-Way Process of Accommodation: Public Perceptions of Integration along the Migration-Mobility Continuum. In Umut Korkut, Gregg Bucken-Knapp, Aidan McGarry, Jonas Hinnfors, and Helen Drake(ed.), The Discourses and Politics of Migration in Europe (109-114). Palgrave Macmillan. ISBN: 9781137310903.
[27] Oesch Daniel(2013). Occupational Change in Europe: How Technology and Education Transform the Job Structure. Oxford Scholarship Online. Print ISBN-13: 9780199680962.

[28] Parry Emma, Stavrou Eleni and Lazarova Mila (2013). Introduction: Human Resource Management across Time and Context: Comparative Research and Global Trends in HRM. In Emma Parry, Eleni Stavrou and Mila Lazarova(ed.), Global Trends in Human Resource Management (1-10). Palgrave Macmillan. ISBN: 9780230354838.

[29] Poutsma Erik, Ligthart Paul E. M. and Dietz Bart (2013). HRM Policies and Firm Performance: The Role of the Synergy of Policies. In Emma Parry, Eleni Stavrou and Mila Lazarova(ed.), Global Trends in Human Resource Management (78-102). Palgrave Macmillan. ISBN: 9780230354838.

[30] Poutsma Erik, Ligthart Paul, Pendleton Andrew and Brewster Chris (2013). The Development of Employee Financial Participation in Europe. In Emma Parry, Eleni Stavrou and Mila Lazarova(ed.), Global Trends in Human Resource Management (179-213). Palgrave Macmillan. ISBN: 9780230354838 .

[31] Pries Ludger and Pauls Robert (2013). Introduction: New Dynamics of Migration and Belonging. In Ludger Pries(ed.), Shifting Boundaries of Belonging and New Migration Dynamics in Europe and China (1-25). Palgrave Macmillan. ISBN: 9780230369726.

[32] Robertson Shanthi (2013). Transnational Student-Migrants and the State. The Education-Migration Nexus. Palgrave Macmillan. ISBN: 9781137267085.

[33] Schröder Martin (2013). Integrating Varieties of Capitalism and Welfare State Research. A Unified Typology of Capitalisms. Palgrave Macmillan. ISBN 9781137310293.

[34] Triandafyllidou Anna (2013B). Circular Migration at the Periphery of Europe: Choice, Opportunity, or Necessity? In Anna Triandafyllidou(ed.), Circular Migration between Europe and its Neighbourhood: Choice or Necessity?(212-236). Oxford: Oxford University Press. ISBN-13: 9780199674510.

[35] Wiseman Alexander W. (2014). Promises and Challenges for Innovation and Entrepreneurship in Education. In Alexander W. Wiseman(ed.), International educational innovation and public sector entrepreneurship(251-274). International Perspectives on Education and Society, Volume 23. Merald Group Publishing Limited. ISBN: 9781781907085. 